\title{
Analysis of Motives behind the Usage of Earnings Management in Practice under the Conditions of Global Economy
}

\author{
Monika Poradova ${ }^{1, *}$ \\ ${ }^{1}$ University of Zilina, Faculty of Operation and Economics of Transport and Communications, \\ Department of Economics, Univerzitna 1, 01026 Zilina, Slovakia
}

\begin{abstract}
.
Research background: Due to the complexity of the issue of global economic result management, the presented paper focused on specific procedures that are used comprehensively in practice in a global environment. The present paper consists of four parts. The first part of the paper deals with the theoretical aspects of the issue addressed. The second part consists of a combination of themes and a description of the methods that are used globally in the economic environment. The third part includes an analysis of countries that were among the largest manipulators of the global economic result from 2009 to 2018. Subsequently, possible impacts on the financial statements are prepared. The fourth part is devoted to the conclusions of the issue addressed.

Purpose of the article: The aim of this paper is to compare the motives that lead to the application of results management practices globally in a global environment.

Methods: In the processing of the present paper, a descriptive method, comparison and synthesis were used.

Findings \& Value added: Accounting standards point out that earnings management can be conducted within the regulatory framework as well as in the conflict of the global environment. The result of the present paper is a comprehensive look at the procedures and issues of earnings management with regard to the functions of the financial statements in the global economy.
\end{abstract}

Keywords: earnings management; global economy; financial statements; accounting standards

JEL Classification: $G 10 ; G 20 ; O 10$

\footnotetext{
* Corresponding author: monika.poradova@fpedas.uniza.sk
} 


\section{Introduction}

The purpose of the financial statements is to provide, by means of financial statements, information about the financial position, operations and changes in the financial position of the company which are used by different groups of persons (hereinafter "Users"). Users also follow the information obtained from the analysis of the financial statements when making global economic decisions. The reason why the financial statements are prepared is to satisfy the usual information needs of most users regarding the financial situation of a particular enterprise [1]. However, the information provided in the financial statements does not provide users with a complete picture of what is needed to make an economic decision. This is because the financial statements largely show the financial consequences of past events and generally do not provide non-financial information.

The financial statements also present the results of the company's management, as well as show how the management took responsibility for the funds entrusted to it. Based on the analysis of financial statements, users have the opportunity to evaluate the results and capabilities of the company's management, so they can make economic decisions. For example, a company's shareholders may assess whether to retain or sell the company's shares, or whether to make certain personnel changes in management [2]. In order for users to be able to make appropriate decisions based on economic information from financial statements, it is necessary that the accounts are kept in such a way as to provide a true and fair view of the company's results [3].

\subsection{Strategic approaches in accounting}

Accounting is not just about interpreting financial results from economic transactions. Accounting also requires the accountant to choose between the alternatives available in accounting policies. The possibility of choosing a strategic approach in accounting brings with it not only positive effects but also undesirable consequences [4]. The consequence of the flexibility allowed can be observed, for example, in two companies which are identical in each financial aspect and carry out the same economic transactions during the year. The financial statements of these companies could only be identified if both apply the same accounting policies and methods, which is highly unlikely given the complexity and flexibility of the accounting standards [5].

The use of different accounting policies and the systematic selection of accounting methods and principles influences and creates different types of the strategic management approach, which are reflected in the nature of accounting:

- Conservative accounting,

- Neutral accounting,

- Liberal accounting,

- Aggressive accounting.

The significant impact of individual types of accounting approaches will be reflected in the improvement of the RNOA (Return on Net Operating Assets) indicator achieved in future periods [6]. The RNOA indicator expresses the return achieved on NOA (Net Operating Assets) t. j. on net operating assets. Net operating assets simply represent assets that are used to carry out operating activities. NOA includes all operating assets and liabilities net of assets and liabilities related to financial activities such as bank credit, investments in securities, etc. [7,8].

Conservative accounting is characterized by the undervaluation of assets and overvaluation of liabilities. An entity shall approach the recognition of revenue that is intentionally recorded late when it is realized. On the other hand, costs are recorded at a faster rate compared to revenue recognition [9]. The essence of neutral accounting lies in 
the selection and use of accounting standards and procedures that minimally distort the picture of the company's results. This accounting can be considered as the zero points between conservative, liberal and aggressive types of accounting. Liberal accounting is a more relaxed approach than the Conservative one. It differs mainly in the degree of more aggressive impact on individual accounting transactions [10].

Assets tend to be overvalued. For the time being, liabilities are reported at a lower book value than they actually should be. Aggressive accounting is based on the maximum overvaluation of assets and at the same time undervaluation of liabilities. The aim is to avoid the creation of any provisions that would incur additional costs. Based on selected accounting policies and approaches to bookkeeping, the entity strives to capitalize on costs as much as possible [11].

\section{Methods}

An entity may generally influence earnings or loss through earnings management. Earnings management is characterized by the fact that the entity takes steps leading to fictitious revenue generation that would not otherwise have arisen without those steps. Through the active manipulation of accounting results, the impression of better company performance is intentionally created. Accounting standards allow the company's management to choose from different types of procedures (balance sheet policy) for different transactions, which will maximize the results that are relevant to a particular user of financial statements. The management of the company both knowingly exceeds the moral as well as the standards resulting from the legislation. In general, it can be stated that earnings management is applied due to the distortion of accounting results in order to achieve certain objectives.

The issue of influencing the global economic result concerns the intentional management of the company's results and performance in the area of revenues, costs, assets and liabilities. The management of the company, or other persons who have the competence and ability to perform interventions in accounting, may intend to interfere in the accounting of the entity in order to adjust the results in such a way as to reduce any qualitative factors discussed in the first chapter of this work. There are several basic motivating factors, or rather motives, for the company's management or other competent persons to decide on such unfair legal or illegal conduct. In general, there are lower types of motives that lead to the company's management to use creative accounting practices. The most frequent reason for using creative accounting in a company is to maximize earnings and present a more positive financial situation of the company.

The aim of this article is to compare the motives that lead to the global application of performance management procedures in a global environment.

Among the basic global types of motives for which, in most cases, the entity chooses to manipulate the earnings or loss. include in particular:

- Reduction of uncertainty and risk level,

- Inability of management to lead the company,

- Pressure from investors to achieve ambitious results,

- Tax optimization,

- Issues of valuation of assets and liabilities.

\section{Results and Discussion}

Motivation of the company's management and accountants for the use of creative accounting through the application of well-thought-out procedures, methods and forms of balancing in accounting companies can stem from specific or corporate motives or a 
combination of them. In the following table 1 shows the types of motivations for creative accounting and possible impacts on the global economic result.

Table 1. Analysis of motivations for creative accounting and possible impacts on the global economic result.

\begin{tabular}{|c|c|c|}
\hline Motivations & $\begin{array}{c}\text { Analysis of possible impacts } \\
\text { on the global economic } \\
\text { result and the quality of } \\
\text { financial statements }\end{array}$ & Reason \\
\hline $\begin{array}{l}\text { The desire of management } \\
\text { to get a bonus }\end{array}$ & $\begin{array}{l}\text {-increased revenues, } \\
\text { - costs and expenses not } \\
\text { listed in full, } \\
\text {-overvalued assets }\end{array}$ & $\begin{array}{l}\text { The bonus depends on } \\
\text { the amount of earnings. } \\
\text { The higher the earnings, } \\
\text { the higher the bonus. } \\
\text { Alternatively, the bonus } \\
\text { is paid out only if a } \\
\text { certain amount of } \\
\text { earnings is achieved. }\end{array}$ \\
\hline $\begin{array}{l}\text { Management is trying to } \\
\text { pay lower taxes }\end{array}$ & $\begin{array}{l}\text {-undervalued revenues, } \\
\text { - costs and expenses are } \\
\text { overestimated, } \\
\text { - overstated liabilities, } \\
\text {-assets may be undervalued }\end{array}$ & $\begin{array}{l}\text { The earnings of the } \\
\text { accounting unit is } \\
\text { adjusted by addable and } \\
\text { deductible items } \\
\text { represents the tax base, } \\
\text { which is taxed by } \\
\text { corporate income tax. } \\
\text { The lower the tax base, } \\
\text { the lower the tax. }\end{array}$ \\
\hline $\begin{array}{l}\text { The company needs a loan } \\
\text { or wants to obtain a loan } \\
\text { with a preferential interest } \\
\text { rate }\end{array}$ & $\begin{array}{l}\text {-minimize uncollectible } \\
\text { receivables, } \\
\text {-overvalued assets, } \\
\text { - undervalued liabilities, } \\
\text {-overvalued revenues }\end{array}$ & $\begin{array}{l}\text { The lower the risk for the } \\
\text { lender, the lower the } \\
\text { interest rate he is willing } \\
\text { to demand for the loan. }\end{array}$ \\
\hline $\begin{array}{l}\text { Increase of the initial share } \\
\text { price upon admission to the } \\
\text { stock exchange, or } \\
\text { correction of the fall in } \\
\text { stock prices in case of } \\
\text { failure to achieve the } \\
\text { planned results }\end{array}$ & $\begin{array}{l}\text {-increased revenues, } \\
\text { - costs and expenses not } \\
\text { listed in full }\end{array}$ & $\begin{array}{l}\text { Management may be } \\
\text { motivated to manipulate } \\
\text { the company's results in } \\
\text { the periods immediately } \\
\text { preceding the IPO. The } \\
\text { higher the demand for } \\
\text { potential investors, the } \\
\text { more capital the IPO will } \\
\text { bring to the company. }\end{array}$ \\
\hline $\begin{array}{l}\text { The company tries to avoid } \\
\text { possible obligations arising } \\
\text { from various legislative } \\
\text { regulations }\end{array}$ & $\begin{array}{l}\text {-undervalued revenues, } \\
\text {-undervalued assets }\end{array}$ & $\begin{array}{l}\text { The occurrence of the } \\
\text { obligation to prepare } \\
\text { financial statements in } \\
\text { accordance with IFRS } \\
\text { standards, or the } \\
\text { emergence of the } \\
\text { obligation to verify the } \\
\text { financial statements by a } \\
\text { financial auditor. }\end{array}$ \\
\hline
\end{tabular}

In connection with the fulfilment of any of the above motives for the manipulation of the global economic result, the entity applies an appropriate method, which will be used to mark the accounting. Emphasis will be placed on minimizing the detection of manipulative behaviour. The choice of the method of intentional interference with the company's result is therefore made on the basis of the desired effect achieved after such an effect on the result. 
The following table 2 lists the countries that were among the largest manipulators of the global economic result from 2009 to 2018.

Table 2. Largest manipulators of the global economic.

\begin{tabular}{|c|c|}
\hline Country & Years \\
\hline China & $2009,2010,2012$ \\
\hline Korea & $2009,2010,2012$ \\
\hline Malaysia & $2009,2010,2012,2017,2018$ \\
\hline Philippines & $2009,2010,2011,2012$ \\
\hline Russia & $2009,2010,2011,2012$ \\
\hline Thailand & $2009,2010,2011,2016,2017$ \\
\hline Hungary & 2013 \\
\hline
\end{tabular}

From the above table we can see that the largest manipulator for the observed period is Malaysia and Thailand.

\subsection{Comparison of basic global motives leading to the application of earnings management practices}

The fact is that earnings management practices are widely used in practice. Companies use increasingly sophisticated methods, so it is sometimes very difficult to obtain concrete evidence of such transactions [12]. Therefore, disclosing an entity's motives for doing so is one alternative to demonstrating the use of those practices.

Efforts to improve financial indicators for obtaining a loan or for compliance with the contractual conditions set by the loan agreement

If a company seeks funding through a loan, the company's management, assisted by earnings management methods, may increase its chances of the bank approving the loan. An improved image of the company's results may affect the future lender when assessing the credit applicant's credit risk [13]. By adjusting its position in the credit risk assessment process through artificially improved results. It can then obtain a better risk score. This may also be reflected in the interest rate, which will take into account the seemingly lower level of risk of the loan applicant [14].

In most cases, companies also finance their activities through bank loans. Liabilities arising from loan agreements in the form of fulfilment of various financial indicators may mean, for example, an increase in the interest rate on a given loan for a company in the event of their breach or non-fulfilment [15].

Increase in the initial share price at the entrance to the stock exchange, if correcting the fall in the share price in case of failure to achieve the intended results

Where a company decides to raise capital to finance its business activities from investors, it shall do so by issuing its own shares and subsequently offering its shares to potential investors on the stock exchange. The process of issuing shares is Initial public offering (IPO). The management of the company may be motivated to manipulate parachutes in periods immediately preceding the IPO. In the process of an IPO, the 
company is being transformed from a privately owned to a publicly-traded company [16]. The demand of potential investors is therefore generally determined by the company's historical performance. This is mainly because there is insufficient information on the market, so potential investors have to rely mainly on the information presented in the financial statements [17]. The demand of potential investors will be influenced by artificially increased positive results from previous periods, which will also increase the price of the issued shares, which will result in the company being able to raise more capital.

For publicly traded companies, the motive for the company's management is to meet the objectives set out in the published financial plans for the next period. Positive results and the fulfilment of the plan will support the demand for shares of the company, and this will bring about an increase in their value. The company's management is expected to do its best to meet the goals, putting the company under pressure from investors, markets, the media and others affected by the company's results.

Modification of results due to tax optimisation and avoidance of possible obligations arising from different legislative regulations

The management of a company operating in a country with a tax system based on progressive taxation may be motivated to optimise taxation by also using management manipulation to achieve results at lower tax rates. In addition, there are various limits imposed by legislation, after which the company is obliged, for example, to be subject to stricter or more frequent supervision [18].

An example of this may be the obligation to draw up financial statements in accordance with IFRS/IAS Standards, the obligation to audit financial statements by a financial auditor after exceeding certain limits defined by law. The trading company is required to draw up financial statements in accordance with IFRSs.

\section{Conclusion}

On the basis of a comparative approach that leads to earnings management, the present article analysed the reasons for manipulating earnings or loss.

The conclusion of the present article is that, despite general awareness of the issue of management of earnings or loss, the application of creative accounting practices in practice cannot be completely eliminated. Even if preventive systems are used which lead to the detection of manipulation in the company's accounts, the complete elimination of misrepresentation cannot be guaranteed. The main obstacle to eliminating management of the global economic outcome is the human factor. It can always find new ways to use the flexibility of accounting standards to manipulate earnings or loss.

The paper is an output of the science project VEGA 1/0210/19 Research of innovative attributes of quantitative and qualitative fundaments of the opportunistic earnings modelling which authors gratefully acknowledge.

\section{References}

1. Abughniem, M. S., Hamdan, A. (2019). Corporate sustainability as an antecedent to the financial performance: an empirical study. Polish Journal of Management Studies, 20(2), 35-44.

2. Svabova, L., Valaskova, K., Durana, P., Kliestik, T. (2020). Dependency Analysis Between Various Profit Measures and Corporate Total Assets for Visegrad Group's Business Entities. Organizacija, 53(1), 80-90. 
3. Silva, D. F. D., Ferreira, L., De Almeida-Filho, A.T. (2020). A new preference disaggregation TOPSIS approach applied to sort corporate bonds based on financial statements and expert's assessment. Expert systems with applications, 152, 113369.

4. Kramarova, K., Valaskova, K. (2020). Application of Chosen Fraudulent Detection Technique in the Slovak Business Environment. In SHS Web of Conferences, 74, 01019.

5. Onuferova, E., Cabinova, V., Dzurov Vargova, T. (2020). Analysis of modern methods for increasing and managing the financial prosperity of businesses in the context of performance: a case study of the tourism sector in Slovakia. Oeconomia Copernicana, 11(1), 95-116.

6. Amir, E., Kama, I., Livnat, J. (2011). Conditional versus unconditional persistence of RNOA components: implications for valuation. Review of accounting studies, 16(2), 302-327.

7. Tran, D. V. (2020). Bank earnings management and dividend policy under agency problem contexts. Annals of financial economics, 15(2), 2050005.

8. Rahman, A., Rozsa, Z., Cepel, M. (2018). Trade Credit and Bank Finance - Evidence from the Visegrad Group. Journal of Competitiveness, 10(3), 132-148.

9. Ayu, M., Gamayuni, R. R., Urbanski, M. (2020). The impact of environmental and social costs disclosure on financial performance mediating by earning management. Polish Journal of Management Studies, 21(1), 74-86.

10. Sumiyana, S. (2020). Different characteristics of the aggregate of accounting earnings between developed and developing countries: Evidence for predicting future GDP. Journal of international studies, 13(1), 58-80.

11. Dominguez, K. M. E. (2019) Stabilization or Manipulation?. US Treasury Approach Policy Identification, 1-30.

12. Khuong, N. V., Liem, N. T., Minh, M. T. H. (2020). Earnings management and cash holdings: Evidence from energy firms in Vietnam. Journal of international studies, 13(1), 247-261.

13. Valaskova, K., Spuchlakova, E., Adamko, P. (2015). Non-parametric bootstrap method in risk management. Procedia Economics and Finance, 24, 701-709.

14. Siekelova, A., Podhorska, I. (2020). Earnings Indicators under the Condition of Globalization. In SHS Web of Conferences, 74, 01031.

15. Kovacova, M., Kliestik, T., Valaskova, K., Durana, P., Juhaszova, Z. (2019). Systematic review of variables applied in bankruptcy prediction models of Visegrad group countries. Oeconomia Copernicana, 10(4), 743-772.

16. Purayil, P. V., Lokuse, P. J. J. (2020). Ownership dilution and earnings management: evidence from Indian IPOs. Managerial finance, 46(3), 344-359.

17. Hollowell, J. C., Kollar, B., Vrbka, J., Kovalova, E. (2019). Cognitive DecisionMaking Algorithms for Sustainable Manufacturing Processes in Industry 4.0: Networked, Smart, and Responsive Devices. Economics, Management, and Financial Markets, 14(4), 9-15.

18. Svabova, L., Kramarova, K., Chutka, J., Strakova, L. (2020). Detecting earnings manipulation and fraudulent financial reporting in Slovakia. Oeconomia Copernicana, 11(3), 485-508. 